\title{
EFFECT OF PROBIOTIC WITH ENZYMES MIXTURE AND DIETARY FAT SOURCE ON BROILER'S PERFORMANCE DURING FINISHER PHASE
}

\author{
El-Faham, A.I., H.A. Thabet and A.Y.M. Abdelhady \\ Poultry Production Department, Fac. Agric., Ain Shams Univ., Cairo, Egypt
}

(Received 3/6/2018, accepted 15/7 /2018)

\section{SUMMARY}

\begin{abstract}
A $\mathrm{n}$ experiment was conducted to determine and compare the differences in production performance, carcass characteristics and economic evaluation of broiler chicks fed two different dietary oil sources (Soybean oil and palm oil), during finisher phase, (5-6 wks.) of age, with different mixture products of probiotic with multi enzymes (Zado or Amphi-Bact each at $0.5 \mathrm{~kg} / \mathrm{ton}$ ). A total of 180 unsexed five weeks of age Hubbard broiler chicks were distributed equally in a completely randomized design with 2 oil sources (O) $x 3$ feed additives $(\mathrm{F})$, resulting in 6 treatments with 3 replicates of 10 chicks each. The results indicated that live body weight (LBW), daily weight gain (DWG), daily feed intake (DFI) and feed conversion ratio $(\mathrm{FCR})$ were not affected significantly by oil source $(\mathrm{O})$, feed additives $(\mathrm{F})$ and their interaction $(\mathrm{O} * \mathrm{~F})$. The best performance index (PI) and production efficiency factor (PEF) were detected for the chickens fed diets incorporated with, soy oil (116.83 and 333.82) and Zado supplementation being (118.03 and 337.24), respectively. Protein conversion ratio (PCR) and energy conversion ratio (ECR) were improved in response to dietary palm oil and Zado supplementation without significant difference between treatments. Carcass traits, edible parts and drumstick traits were not altered by oil source $(\mathrm{O})$, feed additives $(\mathrm{F})$ and their interaction $(\mathrm{O} \times \mathrm{F})$. Economic evaluation showed that, relative economic efficiency was improved for broiler chickens fed palm oil diets or soy oil + Zado $(0.5 \mathrm{~kg} / \mathrm{kg})$ diets. Finally, it could be concluded that, using palm oil or soybean oil with Zado $(0.5 \mathrm{~kg} / \mathrm{ton})$ in finisher diets of Hubbard broiler chickens enhanced economic efficiency without adverse effect on many performance traits.
\end{abstract}

Keywords: Dietary fat, probiotic, enzymes, broiler, performance, carcass.

\section{INTRODUCTION}

Producers of poultry aim to provide high quality, homogenous products in as short a time as possible at minimal cost. Improving poultry performance by dietary manipulation has been the goal of nutritionists and using feed additives like enzymes (Zangiabadi and Torki, 2010), Probiotic (Gill and Prasad, 2008 and Noufain et al., 2008) and probiotic with enzymes (Rahman et al., 2013) to improve performance, health status and dietary nutrient utilization has become popular during the last 15 years.

Bedford and Morgan (1996) concluded that exogenous enzymes could improve digestion for protein, starch and fat by removing the anti-nutritional factors, which interfere with normal processes of digestion or by digestion of fiber components that would otherwise pass undigested into the environment and extend the use of enzyme to play a significant role in health of the digestive tract. Moreover, several reports indicated that dietary enzymes or probiotic improve the health status and performance of poultry through enhancements in immune response, manipulation of gut microflora and pathogen inhibition, histological alterations in small intestine tissue and changes in blood biochemical parameters (Kalmendal and Tauson, 2012; and Deriu et al., 2013).

An Egyptian patented product (Zadoß), which is commercial anaerobic probiotic bacteria with enzyme mixture has been shown to improve broiler productivity and recorded higher dressing and immune organs relative weight at 42 days of broiler chicken age (Safaa, 2013). Moreover, El-Sanhoury and Ahmed (2017) indicated that the use of (Zado®) at $0.5 \mathrm{~kg} /$ ton broiler feed affect positively in the body weight, feed conversion ratio, intestine enzymes activities and good of economic efficiency. In addition, dietary Zado ${ }^{\circledR}$ has a favor effects on lipid metabolism and modifies blood metabolites. However, it has been reported also that enzyme supplementation influences the absorption of fats and 
fatty acids as well as fat-soluble micro-constituents contained in the diets (Danicke et al., 1999). On the other hand, several reports related to improve broiler performance resulting from adding different dietary oil and fat sources to broiler diets (Azman et al., 2005; Nematallah et al., 2014 and Abdulla et al., 2016). However, many conflicting and inconsistent reports appeared in literature about the performance of growing chicks that fed diets supplemented with vegetable oils. Abou El-Wafa et al. (2000) studied the effect of replacing soybean oil with different sources of oil (corn oil and sunflower oil) and fats (Camel fat and margarine) in broiler diets. They found that added oils or fats improved growth rate and feed conversion compared with animal fats, however, they found no significant differences in carcass characteristics due to feeding either the tested oils or fats. Also, Abdulla et al. (2016) found that the lower average daily gain was observed for broiler chickens fed linseed oil compared with soybean oil and palm oil and no significant differences in daily feed intake and feed conversion ratio were found among the various dietary oils. On the contrary, Ayad et al. (2015) showed that feeding broiler chicks on palm oil at $3 \%$ or on free fat diet had superior effects on final productive performance of chicks compared to feeding on $3 \%$ soybean oil.

Little information is available regarding the relationship between Zado or Amphi-Bact as probiotic with enzymes mixture products and performance of broiler chicks fed diets with different sources of oil (soybean oil and palm oil) during finisher phase. So, the objective of this study was to evaluate the growth performance, carcass characteristics and economic efficiency of broiler chicks fed finisher diets (5-6 wks of age) containing different types of traditional oil sources (soybean oil and palm oil) with or without probiotic with enzyme products (Zado or Amphi-Bact).

\section{MATERIALS AND METHODS}

This experiment was conducted at Poultry Experimental Unit, Agriculture Research Station, Qalyubia Governorate, Faculty Agriculture, Ain Shams University.

\section{Birds, housing and experimental design:}

A total of 180 one day old Hubbard broiler chicks (mixed sex) were divided into 6 equal treatments groups, each included 3 replicates with 10 chicks, which were housed into 18 experimental cages in threedeck cage system and received the experimental diets and water in electrically heated battery brooders with raised wire floors. Environmental temperature was maintained at $32 \pm 0.5^{\circ} \mathrm{C}$ during the first week of life and then decreased gradually until reaching $24 \pm 0.5^{\circ} \mathrm{C}$ at 6 weeks of age with a twenty-four hours light program. Chicks were vaccinated against main diseases (Marke's, Newcastle and Infectious Bronchitis). The growth experiment was carried out from 5 to 6 weeks of age. A typical starter (0-2 weeks), grower (34 weeks) and finisher (5-6 weeks) diets based on corn-soybean meal diets were formulated to meet the nutrient requirements of the broiler chicks (NRC, 1994) which are presented in Table (1).

At finisher period (5-6 weeks), the first and second treatment groups were served as control and fed basal finisher diets with soybean oil or palm oil, respectively. While, the other four groups received the basal finisher diets (soybean oil or palm oil) supplemented with commercial probiotic with enzymes mixture products (Zado®, a mix of anaerobic bacteria and xylanases (2.3 unit/g), cellulases (7.1 unit/g), alpha amylase $(61.5 \mathrm{unit} / \mathrm{g})$ and protease $(29.2 \mathrm{unit} / \mathrm{g})$ in a powder form or Amphi-Bact@, a mix of lactic acid bacteria and 34.5 units/g total enzymes, (Amylase, cellulase, Beta-glucanase and Hemicellulase).

\section{Productive performance:}

Measurements of live body weight (LBW) and feed intake (FI) were recorded by replicate and mortality was recorded daily. From these data, daily weight gain (DWG), daily feed intake (DFI), feed conversion ratio (FCR), protein conversion ratio (PCR), energy conversion ratio (ECR) were calculated. Performance index (PI) and production efficiency factor (PEF) were calculated according to North (1981) and Emmert (2000), respectively.

\section{Slaughter traits:}

Four chickens of six weeks of age per treatment were selected for calculation of carcass edible and inedible parts, carcass cuts (neck, wings, drum sticks, thighs and breast \%) and some drumstick traits (\% skin, muscle and bone). 
Table (1): Feed ingredients and calculated analyses of basal and experimental diets.

\begin{tabular}{|c|c|c|c|c|c|c|c|c|}
\hline \multirow{3}{*}{ Ingredients } & \multirow{3}{*}{$\begin{array}{c}\text { Starter } \\
0-2 \\
\text { weeks }\end{array}$} & \multirow{3}{*}{$\begin{array}{c}\text { Grower } \\
3-4 \\
\text { weeks }\end{array}$} & \multicolumn{6}{|c|}{ Finisher 5-6 weeks } \\
\hline & & & \multicolumn{3}{|c|}{ Soybean Oil } & \multicolumn{3}{|c|}{ Palm Oil } \\
\hline & & & None & $\begin{array}{c}\text { Zado } \\
0.5 \mathrm{Kg} / \text { Ton }\end{array}$ & $\begin{array}{l}\text { AmphiBact } \\
0.5 \mathrm{Kg} / \text { Ton }\end{array}$ & None & $\begin{array}{c}\text { Zado } \\
0.5 \mathrm{Kg} / \text { Ton }\end{array}$ & $\begin{array}{l}\text { AmphiBact } \\
0.5 \mathrm{Kg} / \text { Ton }\end{array}$ \\
\hline Corn yellow (grains) & 52.05 & 55.91 & 56.80 & 56.80 & 56.80 & 56.80 & 56.80 & 56.80 \\
\hline Soybean Meal (44\%) & 31.50 & 30.00 & 28.25 & 28.25 & 28.25 & 28.25 & 28.25 & 28.25 \\
\hline Corn Gluten Meal (62\%) & 7.20 & 4.86 & 4.40 & 4.40 & 4.40 & 4.40 & 4.40 & 4.40 \\
\hline Soybean Oil & 3.00 & 3.65 & 5.00 & 5.00 & 5.00 & - & - & - \\
\hline Palm Oil & - & - & - & - & - & 5.00 & 5.00 & 5.00 \\
\hline Wheat Bran & 2.00 & 1.50 & 2.00 & 2.00 & 2.00 & 2.00 & 2.00 & 2.00 \\
\hline Di-Calcium Phosphate & 1.85 & 1.60 & 1.34 & 1.34 & 1.34 & 1.34 & 1.34 & 1.34 \\
\hline Calcium Carbonate & 1.30 & 1.50 & 1.35 & 1.35 & 1.35 & 1.35 & 1.35 & 1.35 \\
\hline DL-Methionine & 0.29 & 0.28 & 0.21 & 0.21 & 0.21 & 0.21 & 0.21 & 0.21 \\
\hline L-Lysine HCL & 0.21 & 0.10 & 0.05 & 0.05 & 0.05 & 0.05 & 0.05 & 0.05 \\
\hline Premix & 0.30 & 0.30 & 0.30 & 0.30 & 0.30 & 0.30 & 0.30 & 0.30 \\
\hline Salt $(\mathrm{NaCl})$ & 0.30 & 0.30 & 0.30 & 0.30 & 0.30 & 0.30 & 0.30 & 0.30 \\
\hline \multicolumn{9}{|l|}{ Calculated analysis: } \\
\hline Crude Protein \% & 23.06 & 21.18 & 20.06 & 20.06 & 20.06 & 20.06 & 20.06 & 20.06 \\
\hline ME Kcal/ Kg diet & 3031 & 3076 & 3207 & 3207 & 3207 & 3171 & 3171 & 3171 \\
\hline Calcium $\%$ & 1.00 & 1.01 & 0.90 & 0.90 & 0.90 & 0.90 & 0.90 & 0.90 \\
\hline Available Phosphorus \% & 0.50 & 0.45 & 0.40 & 0.40 & 0.40 & 0.40 & 0.40 & 0.40 \\
\hline Lysine $\%$ & 1.30 & 1.15 & 1.06 & 1.06 & 1.06 & 1.06 & 1.06 & 1.06 \\
\hline Methionine \& Cysteine \% & 0.97 & 0.93 & 0.84 & 0.84 & 0.84 & 0.84 & 0.84 & 0.84 \\
\hline Price & 7022 & 6875 & 6657 & 6684 & 6689 & 6404 & 6434 & 6439 \\
\hline
\end{tabular}

Each 3 Kg of premix contains: Vitamins: A: 12000000 IU; Vit. D3 2000000 IU; E: 10000 mg; K3: 2000 mg; B1:1000 mg; B2: 5000 mg; B6:1500 mg; B12: 10 mg; Biotin: $50 \mathrm{mg}$; Choline chloride: $250000 \mathrm{mg}$; Pantothenic acid: 10000 mg; Nicotinic acid: $30000 \mathrm{mg}$; Folic acid: $1000 \mathrm{mg}$; Minerals: Mn: $60000 \mathrm{mg}$; Zn: $50000 \mathrm{mg}$; Fe: $30000 \mathrm{mg}$; Cu: $10000 \mathrm{mg}$; I: $1000 \mathrm{mg}$; Se: $100 \mathrm{mg}$ and Co: $100 \mathrm{mg}$.

\section{Economic traits:}

The economic efficiency of broiler chickens was calculated according to the local market price of feed ingredients as well as feed additives (Zado® and AmphiBact®), at the time of the experiment.

\section{Statistical analysis:}

The collected data were subjected to two-way analysis of variance to detect the effects of oil source $(\mathrm{O})$, feed additives $(\mathrm{F})$ and their interactions $(\mathrm{O} * \mathrm{~F})$ using the general linear model (GLM) procedure of SAS (SAS, 2004) according to the following model:

$\mathrm{Yijk}=\mu+\mathrm{Oi}+\mathrm{Fj}+(\mathrm{O} * \mathrm{~F}) \mathrm{ij}+\mathrm{e}_{\mathrm{ijk}}$.

Where: Yijk $=$ Trait measured, $\mu=$ Overall mean, $\mathrm{Oi}=$ Oil source, $\mathrm{I}=(1,2), \mathrm{Fj}=$ Feed additives, $\mathrm{j}=(1,2$, 3),

$(\mathrm{O} * \mathrm{~F}) \mathrm{ij}=$ interaction between oil source and feed additives and $\mathrm{e}_{\mathrm{ijk}}=$ Experimental random error.

In addition, Duncan's multiple range test (Duncan, 1955) was used to separate means when separation was relevant. Statistical significance was accepted at probability level of $(\mathrm{P} \leq 0.05)$.

\section{RESULTS AND DISCUSSION}

\section{Productive:}

Effect of different dietary treatments on live body weight (LBW), daily weight gain (DWG), daily feed intake (DFI) and feed conversion ratio (FCR) during experimental period are presented in Table (2). 
In general, no significant effect was observed in LBW and DWG among the experimental groups during experimental period (5-6 wks.). It is worth to note that broiler chicks fed (palm oil) diets reflected the lowest insignificant DWG compared with those fed (Soybean bean soil) diets and the corresponding values were (79.30 and 80.58) respectively. On the other hand, inclusion of broiler diets with Zado and Amphi-Bact led to numerical decrease in the DWG by 1.68 and $4.52 \%$, respectively compared with that fed non-dietary probiotic additive diets (NPA).

Data in Table (2) indicate that (DFI) per chick (g/d) increased by feeding (soybean oil) diets compared with those fed (palm oil) diets, the corresponding figures were 147.67 versus $146.96(\mathrm{~g} / \mathrm{c} / \mathrm{d})$, without significant differences. However, inclusion of Zado or Amphi-Bact in the broiler diets reflected insignificant reduction in the (DFI) compared with NPA diets (142.39, 146.70 versus 152.89), respectively. Feed conversion ratio (FCR) showed the same trend since chicks fed soybean oil diets were more efficient in converting their food into BWG compared with those fed palm oil diets. The corresponding figures were 1.86 versus 1.88 without significant differences between the two treatments. In the same order, the figures of FCR indicated insignificant differences between chicks fed diets supplemented with different probiotic additive compared with those fed NPA diets. The best FCR was detected for the chickens fed diets supplemented with $0.5 \mathrm{~kg} /$ ton Zado (1.80) and the worst FCR were found in chicken fed $0.5 \mathrm{~kg} / \mathrm{ton}$ Amphi-Bact (1.92) compared with that fed NPA diets (1.88), which could be due to the lowest DWG in case of (Amphi-Bact) and lowest FI in case of Zado supplemented groups compared with the NPA groups. Results in Table (2), indicated that inclusion of (soybean oil) in the broiler diets increased DWG and DFI and improved FCR, while Zado supplementation reduced DFI and improved FCR through the trail which indicate that either soybean oil or Zado indeed exerted some positive effect on broilers. Results of the current study agree with those by Abdulla et al. (2016) who fed broiler with different oil sources (palm oil, soybean oil or linseed oil) and observed no significant differences in DFI and FCR among the various dietary oils. Also, Velasco et al. (2010) found that BWG of broiler chickens was not influenced by feeding either palm oil or sunflower oil, but feed intake and FCR were inferior $(\mathrm{P}<0.001)$ in birds fed palm oil diets. On the contrary, Ayad et al. (2015) showed that broiler chicks fed $3 \%$ palm oil had superior effects on final productive performance of chicks compared to feeding 3\% soybean oil. On the other hand, previous studies examining the effects of probiotics showed inconsistent effect on broiler performance (Ergum et al., 2000, Kumprechtova et al., 2000 and Willis et $a l ., 2007$ ) who found no or minimal effect of probiotic supplementation on broiler performance. However, other researchers have found that probiotics were the most effective growth promoter and improved BWG and FCR in chickens (Amerah et al., 2012 and Safaa, 2013).

\section{Performance index (PI) and production efficiency factor (PEF)}

Insignificant differences were observed in PI and PEF with experimental treatments during experimental period (Table 2). PI Figures ranged between 116.83 and 113.08 for (oil sources) and 118.03 and 113.13 for (dietary additives). In the same order, the figures of PEF indicated insignificant differences between chicks fed diets containing different oil sources (333.82 versus 323.13) or different dietary additives (337.24 and 323.24) compared with those fed NPA diets (324.95). The best PI and PEF were detected for the chickens fed diets incorporated with, soybean oil (116.83 and 333.82) and Zado supplementation being (118.03 and 337.24), respectively. In this connection, Rayan et al. (2015) showed that commercial multi enzymes (phytabex plus) supplementation in cobb broiler diets at level of $200 \mathrm{~g} /$ ton had the best PI and PEF as compared with control diet. In addition, Zado supplementation to broiler diets improved broiler productivity and might improve immunity (Safaa, 2013).

\section{Protein conversion ratio (PCR) and energy conversion ratio (ECR)}

Results of PCR and ECR of broiler chicken at 6wks of age are presented in Table (2). Results indicated that PCR and ECR were improved in response to dietary palm oil compared to soybean oil being 0.37 versus 0.38 for PCR and 5.98 versus 6.08 for ECR, respectively, without any significant differences. This might be due to the fact that broiler chickens fed palm oil diets contained lower energy, lower calorie/protein ratio and lower daily feed intake $(146.96, \mathrm{~g} / \mathrm{d})$ could be related to the fact that birds met their energy requirements by increasing feed intake. According to Lesson and Summers (1991), birds have the ability to meet their energy requirements to certain extent by increasing feed consumption. In the same order, the figures of PCR and ECR indicated insignificant differences between chickens fed diets supplemented with dietary feed additives compared with those fed NPA diets. 
Table (2): Effect of dietary treatments on live body weight (LBW), daily weight gain (DWG), daily feed intake (DFI), feed conversion ratio (FCR) and growth rate (GR) within 35-42 days of age.

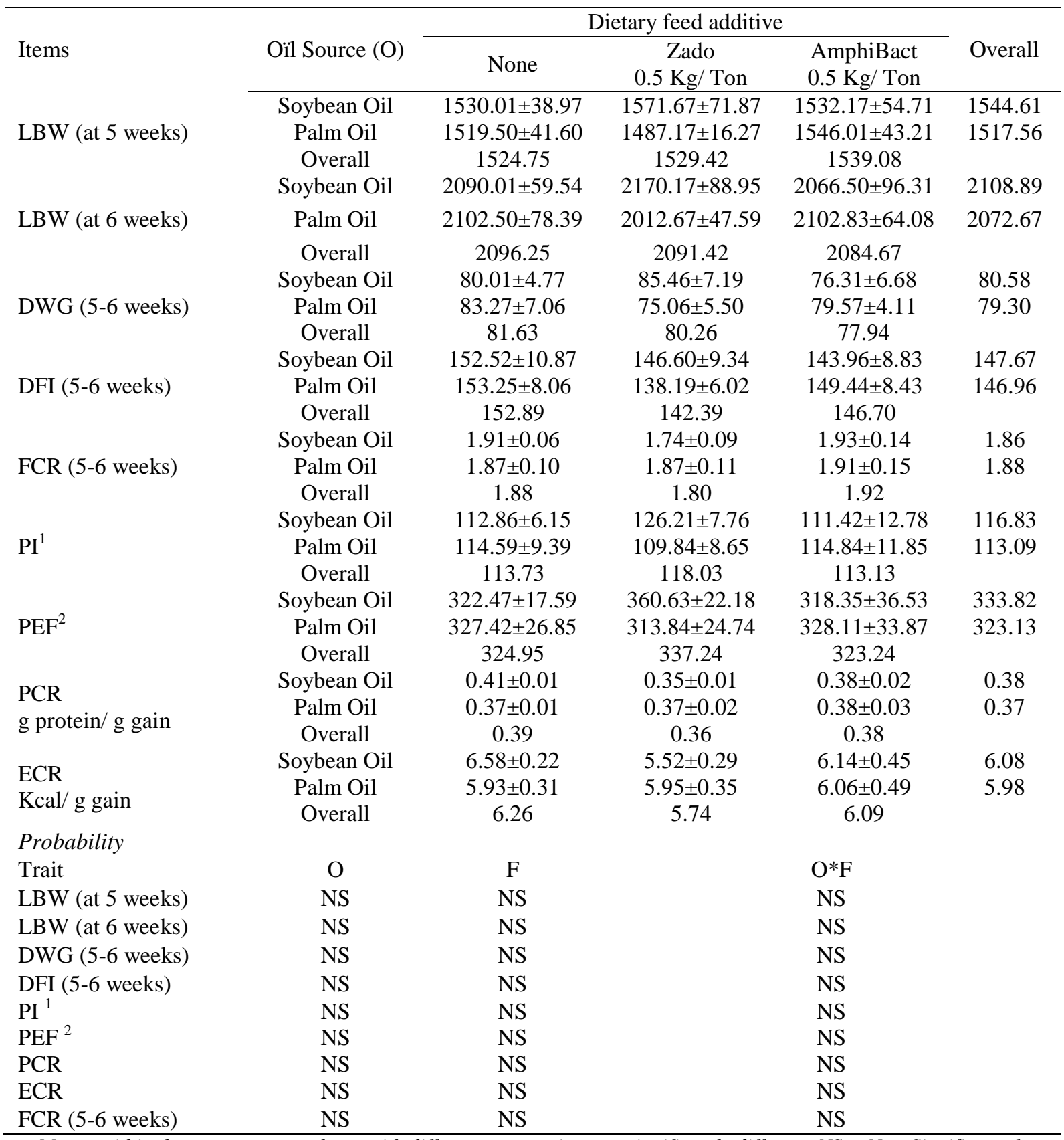

Means within the same row or column with different superscripts are significantly different. NS = Non-Significant. 1: North (1981), 2: Emmert (2000).

The best PCR and ECR was detected for the chickens fed diets supplemented with Zado ( 0.36 and 5.74), respectively. While, the worst PCR (0.39) and ECR (6.26) were found in chickens fed NPA diets. However, the differences between treatments were insignificant. In this connection, Younis et al. (2016) reported that broilers fed diets supplemented with coated organic acids, essential oils or probiotic tend to improve PCR by $6.5,5.6$ and $44.79 \%$, respectively compared with those fed the control diets. 


\section{Carcass characteristics and some drumstick traits:}

Data in Table (3 and 4) shows the effect of different treatments on carcass characteristics and some drumstick traits of broiler chickens slaughtered at the end of 42 days of age. Treatments had no significant effects on carcass $\%$, total edible parts $\%$ (hot carcass weight + giblets weight) $\%$, body fats $\%$, breast $\%$ and drumstick traits (skin \%, muscle $\%$ or bone $\%$ ).

Table (3): Effect of dietary treatments on carcass traits and edible parts (\%).

\begin{tabular}{|c|c|c|c|c|c|}
\hline \multirow[b]{2}{*}{ Items } & \multirow[b]{2}{*}{ Oïl Source (O) } & \multicolumn{3}{|c|}{ Dietary Enzymatic Additive (E) } & \multirow[b]{2}{*}{ Overall } \\
\hline & & None & $\begin{array}{c}\text { Zado } \\
0.5 \mathrm{Kg} / \text { Ton }\end{array}$ & $\begin{array}{l}\text { AmphiBact } \\
0.5 \mathrm{Kg} / \text { Ton }\end{array}$ & \\
\hline \multirow{3}{*}{ Dressed carcass } & Soybean Oil & $72.75 \pm 1.10$ & $74.77 \pm 0.68$ & $75.14 \pm 0.43$ & 74.22 \\
\hline & Palm Oil & $74.37 \pm 1.02$ & $73.06 \pm 0.99$ & $73.59 \pm 0.44$ & 73.67 \\
\hline & Overall & 73.56 & 73.91 & 74.37 & \\
\hline \multirow{3}{*}{ Breast } & Soybean Oil & $41.75 \pm 2.40$ & $41.88 \pm 0.65$ & $42.50 \pm 0.78$ & 42.04 \\
\hline & Palm Oil & $39.80 \pm 1.57$ & $40.91 \pm 0.28$ & $41.10 \pm 1.46$ & 40.60 \\
\hline & Overall & 40.78 & 41.39 & 41.80 & \\
\hline \multirow{3}{*}{ Body Fats * } & Soybean Oil & $2.79 \pm 0.74$ & $1.96 \pm 0.27$ & $1.71 \pm 0.40$ & 2.15 \\
\hline & Palm Oil & $1.95 \pm 0.54$ & $2.45 \pm 0.29$ & $2.30 \pm 0.41$ & 2.23 \\
\hline & Overall & 2.37 & 2.20 & 2.01 & \\
\hline \multirow{3}{*}{ Liver } & Soybean Oil & $2.17 \pm 0.10$ & $1.97 \pm 0.09$ & $1.90 \pm 0.22$ & 2.01 \\
\hline & Palm Oil & $1.71 \pm 0.23$ & $1.97 \pm 0.14$ & $2.06 \pm 0.22$ & 1.92 \\
\hline & Overall & 1.94 & 1.97 & 1.98 & \\
\hline \multirow{3}{*}{ Gizzard } & Soybean Oil & $1.57 \pm 0.08$ & $1.27 \pm 0.07$ & $1.36 \pm 0.11$ & 1.40 \\
\hline & Palm Oil & $1.49 \pm 0.02$ & $1.34 \pm 0.11$ & $1.41 \pm 0.13$ & 1.41 \\
\hline & Overall & 1.53 & 1.30 & 1.38 & \\
\hline \multirow{3}{*}{ Heart } & Soybean Oil & $0.59 \pm 0.04$ & $0.50 \pm 0.02$ & $0.49 \pm 0.03$ & 0.53 \\
\hline & Palm Oil & $0.54 \pm 0.03$ & $0.52 \pm 0.03$ & $0.49 \pm 0.01$ & 0.52 \\
\hline & Overall & 0.56 & 0.52 & 0.49 & \\
\hline \multirow{3}{*}{ Giblets } & Soybean Oil & $4.33 \pm 0.09$ & $3.74 \pm 0.17$ & $3.74 \pm 0.16$ & 3.94 \\
\hline & Palm Oil & $3.74 \pm 0.25$ & $3.84 \pm 0.19$ & $3.95 \pm 0.36$ & 3.84 \\
\hline & Overall & 4.04 & 3.79 & 3.85 & \\
\hline \multirow{3}{*}{ Total edible } & Soybean Oil & $77.09 \pm 1.19$ & $78.51 \pm 0.79$ & $78.89 \pm 0.27$ & 78.17 \\
\hline & Palm Oil & $78.11 \pm 0.77$ & $76.90 \pm 0.83$ & $77.55 \pm 0.09$ & 77.53 \\
\hline & Overall & 77.60 & 77.71 & 78.22 & \\
\hline \multicolumn{6}{|l|}{ Probability } \\
\hline Trait & $\mathrm{O}$ & $\mathrm{F}$ & & $\mathrm{O} * \mathrm{~F}$ & \\
\hline Dressed carcass \% & NS & NS & & NS & \\
\hline Breast $\%$ & NS & NS & & NS & \\
\hline Body fats $\% *$ & NS & NS & & NS & \\
\hline Breast \% & NS & NS & & NS & \\
\hline Liver $\%$ & NS & NS & & NS & \\
\hline Gizzard \% & NS & NS & & NS & \\
\hline Heart \% & NS & NS & & NS & \\
\hline Giblets $\%$ & NS & NS & & NS & \\
\hline Total edible $\%$ & NS & NS & & NS & \\
\hline
\end{tabular}


Egyptian J. Nutrition and Feeds (2018)

Table (4): Effect of dietary treatments on some drumstick traits.

\begin{tabular}{|c|c|c|c|c|c|}
\hline \multirow[b]{2}{*}{ Items } & \multirow[b]{2}{*}{$\begin{array}{l}\text { Oïl Source } \\
\text { (O) }\end{array}$} & \multicolumn{3}{|c|}{ Dietary Feed Additive $(\mathrm{F})$} & \multirow[b]{2}{*}{ Overall } \\
\hline & & None & $\begin{array}{c}\text { Zado } \\
0.5 \mathrm{Kg} / \text { Ton }\end{array}$ & $\begin{array}{l}\text { AmphiBact } \\
0.5 \mathrm{Kg} / \text { Ton }\end{array}$ & \\
\hline \multirow{3}{*}{ Drum Sticks \%* } & Soybean Oil & $13.52 \pm 1.05$ & $13.85 \pm 0.49$ & $13.07 \pm 0.22$ & 13.48 \\
\hline & $\begin{array}{c}\text { Palm Oil } \\
\text { Overall }\end{array}$ & $\begin{array}{c}13.34 \pm 0.57 \\
13.43\end{array}$ & $\begin{array}{c}13.08 \pm 0.42 \\
13.47\end{array}$ & $\begin{array}{c}12.86 \pm 0.55 \\
12.96\end{array}$ & 13.09 \\
\hline & Soybean Oil & $10.65 \pm 1.42$ & $10.12 \pm 1.30$ & $9.37 \pm 1.06$ & 10.05 \\
\hline \multirow[t]{2}{*}{ Drumstick skin \% } & $\begin{array}{c}\text { Palm Oil } \\
\text { Overall }\end{array}$ & $\begin{array}{c}10.02 \pm 0.80 \\
10.34\end{array}$ & $\begin{array}{c}10.52 \pm 0.66 \\
10.32\end{array}$ & $\begin{array}{c}9.69 \pm 0.27 \\
9.53\end{array}$ & 10.08 \\
\hline & Soybean Oil & $66.05 \pm 1.50$ & $68.21 \pm 1.22$ & $68.70 \pm 0.92$ & 67.65 \\
\hline \multirow[t]{2}{*}{ Drumstick muscle $\%$} & $\begin{array}{c}\text { Palm Oil } \\
\text { Overall }\end{array}$ & $\begin{array}{c}69.06 \pm 0.54 \\
67.55\end{array}$ & $\begin{array}{c}65.66 \pm 5.18 \\
66.94\end{array}$ & $\begin{array}{c}65.53 \pm 0.77 \\
67.11\end{array}$ & 66.75 \\
\hline & Soybean Oil & $23.29 \pm 1.52$ & $21.65 \pm 0.33$ & $21.92 \pm 1.86$ & 22.29 \\
\hline Drumstick bone $\%$ & $\begin{array}{l}\text { Palm Oil } \\
\text { Overall }\end{array}$ & $\begin{array}{c}20.91 \pm 1.02 \\
22.10\end{array}$ & $\begin{array}{c}23.81 \pm 5.45 \\
22.73\end{array}$ & $\begin{array}{c}24.77 \pm 0.91 \\
23.34\end{array}$ & 23.16 \\
\hline \multicolumn{6}{|l|}{ Probability } \\
\hline Trait & $\mathrm{O}$ & $\mathrm{F}$ & & $\mathrm{O} * \mathrm{~F}$ & \\
\hline Drum Sticks \%* & NS & NS & & NS & \\
\hline Drumstick skin \% & NS & NS & & NS & \\
\hline Drumstick muscle $\%$ & NS & NS & & NS & \\
\hline Drumstick bone $\%$ & NS & NS & & NS & \\
\hline
\end{tabular}

Chickens fed soybean oil diets reflected the highest carcass and total edible parts percentages compared with that fed palm oil diets. However, carcass\% increased by $0.74 \%$ (74.22 versus $73.67 \%)$ and total edible parts $\%$ showed similar trend $(78.17$ versus $77.53 \%)$. On the other hand, broiler chickens given Amphi-Bact (0.5 kg/ton) led up to clear numerical increase in the carcass \% (74.37), total edible parts\% (78.22) and breast \% (41.80) compared with other dietary treatments. In this respect, Bobadoye et al. (2008); Alizadeh et al. (2012) and Duraisamy et al. (2013) reported that different fat sources and their combination had no effect on carcass characteristics.

In partial agreement, Abdulla et al. (2016) showed no significant differences in weight of liver, gizzard and heart when broilers were fed palm oil, soybean oil or linseed oil. However, birds fed palm oil recorded higher abdominal fat $(\mathrm{P}<0.05)$ than those of other sources. Moreover, results of the current study agree with those obtained by Ali (1999), Abdel-Azeem and Hamid (2006) and Nematallah et al. (2015) who detected that there were no significant differences in absolute and relative weights of empty carcass, total giblets, abdominal fat and total edible parts between the control group and the birds fed diets supplemented with probiotics.

\section{Economic traits:}

Data for economic evaluation are summarized in Table (5). The economic evaluation was calculated on the basis of prices of local market for feed ingredients, feed additives, one day old chick and $\mathrm{kg}$ of live body weight of chicken during the experimental period. The obtained results showed that palm oil incorporated on the expense of soybean oil supported the calculated economic efficiency percentages of broiler chickens and the corresponding values were 143.21 (110\%) and $132.25(100 \%)$, respectively. On the other hand, it is clear that feeding broiler chicks on NPA diets (without probiotic additive) increased the feeding cost and total cost compared with those fed other dietary treatments. The best economic efficiency and relative economic efficiency were detected for the chickens fed diets incorporated with (soybean oil + Zado) being (15.97 and $166.08 \%$ ), respectively. These results agree with those reported by Tammam (2015) who concluded that both palm oil as traditional oil source and fatty acid mix as untraditional fat source recorded the best economic efficiency compared with soybean oil and other fat sources dry fat and full-fat soy. However, Ibrahim (2005) reported that there was no significant effect of dietary sunflower oil, palm oil, cotton seed oil, distillated fatty acids and nutria fat on economic efficiency of silver Montazah growing chicks. 
Table (5): Effect of dietary treatments on economic traits.

\begin{tabular}{|c|c|c|c|c|c|c|}
\hline \multirow{3}{*}{ Items } & \multicolumn{6}{|c|}{ Dietary Treatments } \\
\hline & \multicolumn{3}{|c|}{ Soybean Oil } & \multicolumn{3}{|c|}{ Palm Oil } \\
\hline & None & $\begin{array}{c}\text { Zado } \\
0.5 \mathrm{Kg} / \text { Ton }\end{array}$ & $\begin{array}{l}\text { AmphiBact } \\
0.5 \mathrm{Kg} / \text { Ton }\end{array}$ & None & $\begin{array}{c}\text { Zado } \\
0.5 \mathrm{Kg} / \text { Ton }\end{array}$ & $\begin{array}{l}\text { AmphiBact } \\
0.5 \mathrm{Kg} / \text { Ton }\end{array}$ \\
\hline Average feed consumption $(\mathrm{Kg})$ & 1.06 & 1.02 & 1.01 & 1.07 & 0.97 & 1.04 \\
\hline Total cost $(\mathrm{LE})^{*}$ & 52.88 & 46.88 & 45.80 & 45.81 & 44.38 & 46.38 \\
\hline Feed cost (LE) & 6.78 & 6.58 & 6.49 & 6.81 & 6.21 & 6.73 \\
\hline Live body weight (Kg) & 2.32 & 2.17 & 2.06 & 2.11 & 2.01 & 2.10 \\
\hline Total return $^{\#}(\mathrm{LE})$ & 58.01 & 54.25 & 51.66 & 52.56 & 50.31 & 52.57 \\
\hline Net return $(\mathrm{LE})$ & 5.11 & 7.37 & 5.86 & 6.75 & 5.93 & 6.18 \\
\hline Economic efficiency & 9.62 & 15.97 & 12.57 & 14.67 & 13.30 & 13.34 \\
\hline Relative economic efficiency & 100.00 & 166.08 & 130.69 & 152.56 & 138.33 & 138.73 \\
\hline Mean economic efficiency & \multicolumn{3}{|c|}{$132.25(100 \%)$} & \multicolumn{3}{|c|}{$143.21(110 \%)$} \\
\hline
\end{tabular}

* Price of 5 wks old chick + incidental costs.

\# According to the local price of Kg LBW, which was 25.00 L.E.

In the same order, similar observations were reported by other investigators Abd-Elsamee and Abd El-Hakim (2002); Abdel-Azeem and Hamid (2006); and Nematallah et al. (2015) who all reported that symbiotic or probiotic improved economic efficiency in broiler diets.

\section{CONCLUSION}

From the present results, it could be stated that, productive performance and carcass characteristics of broiler chickens were not affected by different dietary treatments (oil sources and mixture of probiotic with enzymes) at finisher diets. Moreover, feeding diets containing palm oil or soybean oil + Zado (0.5 $\mathrm{kg} / \mathrm{ton}$ ) presented higher relative economic efficiency.

\section{REFERENCES}

Abdel-Azeem, F. and Hamid, A.A. (2006). Using barley radical with yeast cultures supplementation in broilers diets. Egypt. Poult. Sci., Vol., 26(1): 179-206.

Abd-Elsamee, M.O. and Abd El-Hakim, A.S. (2002). Performance of broiler chicks as affected by using poultry by-product meal and probiotic supplementation. Egypt. Poult. Sci., Vol., 22 (III): 745-761.

Abdulla, N.R.; T.C. Loh; H. Akit; A.Q. and H.L. Foo (2016). Effects of dietary oil sources and calcium to phosphorus levels on growth performance gut morphology and apparent digestibility of broiler chickens. S. Afr. J. Anim. Sci., Vol., (No. 1) 42-53.

Abou El-Wafa, S.; O.M. El-Husseiny and N, Shabaan (2000). Influence of different dietary oil and fat sources on broiler performance. J. Egypt. Poult. Sci., 20: 741-756.

Ali, M.A. (1999). Effect of probiotic addition to broiler rations on performance and some blood constituents. Egypt. Poult. Sci., 19: 161-177.

Alizadeh, S.; M.H. Shahir; H. Manlo; N. Baradaran and Z.A. Kermani (2012). Sunflower oil production wastes (acidulated soap stock) as an energy source in broiler chickens diets. The International and the 4th National Congress on Recycling of Organic Waste in Agriculture, Isfahan, Iran.

Amerah, A.; Van Rensburg, C.J.; Plumstead, P.W.; Kromm, C. and Dunham, S. (2012). Effect of feeding diets containing a probiotic or antibiotic on broiler performance, intestinal mucosa-associated avian pathogenic E. coli and litterwater-soluble phosphorus. J. Appl. Anim. Nutr.1: 7. 
Ayad, H.B.; H. Attia ad M. Ennouri (2015). Effect of oil supplemented diet on growth performance and meat quality of broiler chickens. Adv. Techn. Biol. Med., 4:1.

Azman, M.A.; Ü.H. Cerci and N. Burben (2005). Effects of various dietary fat sources on performance and body fatty acid composition of broiler chickens. Turk J. Vet. Anim. Sci. (29): 811-819.

Bedford, M.R. and Morgan, A.J. (1996). The use of enzymes in poultry diets. World's Poult., Sci. J., 52: 61-68.

Bobadoye, A.O.; G.E. Onibii, A.N. Fakemisin; O.O. Olasupo and B.O. Bobadoye (2008). Replacing maize with palm oil sludge in broiler chicken diets: effect in carcass characteristics, organ weight and muscle development Int. J. Sustain. Crop. 3(6): 1-5.

Danicke, S.; Jeroch, H.; Bottcher, W.; Bedford, M.R. and Ortwin, S. (1999a). Effects of dietary fat type pentosan level and xylanases on digestibility of fatty acids, liver lipids and vitamin $\mathrm{E}$ in broiler. Fett/Lipid. 101(3): 90-100.

Deriu, E.; Liu, J.Z.; Peezeshki, M.; Edwards, R.A.; Ochoa, R.J.; Fang, F.C. and Raffatellu, M. (2013). Probiotic bacteria reduce Salmonella typhimurium intestinal colonization by competing for iron. Cell Host Microbe, 14: 26-36.

Duncan, D.B. (1955). Multiple range and multiple F test. Biometrics, 11: 1-42.

Duraisamy, K.; M. Senthilar and K. Mani (2013). Effect of saturated and unsaturated fat on the performance, serum and meat cholesterol level in broiler, Vet. World, 6(3): 159-162.

El-Sanhoury, M.H.S. and A.M.H. Ahmed (2017). Broiler performance enzymes activity and histological observations affected by multi enzymes complex (Zado®). Egyptian J. Nutrition and Feeds, 20 (2):311-322.

Emmert, J. (2000). Efficiency of phase-feeding in broilers. Proceeding, California Animal Nutrition Conference. May 10-11, Fresno, California, USA.

Ergun, A.; Yalcin S. and Sacakli, P. (2000). The usage of probiotic and zinc bacitracin in broiler rations. Ankara Univ. Vet. 47: 271-280.

Gill, H, and Prasad, J. (2008). Probiotics, immunomodulation and health benefits. Adva. In Exper. Med. and Bio., 606: 423-443.

Ibrahim, S.M. (2005). Effect of different dietary oils on the performance of silver Montazah growing chicks. J. Agric. Sci., Mansour, 30(8): 4439-4449

Kalmendal, R. and R. Tauson (2012). Effects of a xylanase and protease, individually or in combination, nutrient utilization and intestinal morphology in broiler chickens fed a wheat-soybean meal-based diet. Poult. Sci., 91: 1387-1393.

Kumprechtova, D.; Zobac, P. and Kumprecht, I. (2000). The effect of Saccharomyces cerevisiae, Sc. 47 on chicken broiler performance and nitrogen output. Czech J. Anim. Sci., 45: 169-177.-

Lesson, S. and J.D. Summers (1991). Commercial Poultry Nutrition. Published by Uni. Books P.O. Box 1326, Guleph and Ontario, Canada pp. 20-21.

Nematallah, G.M. Ali, A.F. Abdel-Salam; A.A. Radwan; Heba Allah E. Megahid (2015). Modulation of physiological and microbiological broiler state by some growth promoters. Egypt. Poult. Sci., (II): 591-608.

Nematallah, G.M. Ali, Eman, F. El-Daly; A.I. El-Faham; S.A. Ibrahim and M.E. Mohamed (2014). Nutritional and physiological study on using of residual oil (fatty acids and distillated fatty acids) in growing local chick diets. Egyptian J. Nutrition and Feeds, 17 (2):258-269.

North, M.O. (1981). Commercial chicken production. Annual 2nd Edition. Av., Publishing Company I.N.C., West Post Connecticut, USA.

Noufaim, J.C.; Andreattifilho, R.I.; Lima, E.T.; Okamoto, A.S.; Amorim, R.I. and Torres Neto, R. (2008). Detection of $\mathrm{T}$. lymphocytes in intestine of broiler chicks treated with Lacobacillus spp. and challenged with Salmonella entericaSerovar enteritidis. Poult. Sci., 87: 927-933. 
NRC (1994). National Research Council. Nutrient Requirements of Poultry 9th Ed. Composition of Poultry Feedstuffs National Academy Press, Washington, DC, USA. P.P. 61-75.

Rahman, A. Mustari, M. Salauddin and M. M. Rahman (2013). Effects of probiotics and enzymes on growth performance and hematobiochemical parameters in broilers.J. Bangladesh Agril. Univ. 11(1): 111-118.

Rayan, G.N.; A.I. El-Faham and M.A.M. Abdelaziz (2015). Impact of strain different levels of commercial multi enzymes and their interaction on broiler performance and carcass traits. Egypt. Poult. Sci., Vol., 35(II): 471-488.

Safaa, H.M. (2013). Influence of dietary enzymes prepared at ensiling (Zado®) from hatch to 42 days of age on productivity, slaughter traits and blood constituents in broiler chickens Int. J. Poult. Sci. 2(9): 529-537.

SAS, Statistical Analysis Systems (2004). User's Guide Version 8.2, Cary NC, USA.

Tammam, A.M. (2015). Nutritional evaluation of some untraditional feedstuffs in growing chick diets. M.Sc. Thesis, Poult. Nut. Fac. of Agric., Ain Shams Univ. Egypt.

Velasco S1, Ortiz LT, Alzueta C, Rebolé A, Treviño J and Rodríguez ML (2010). Effect of inulin supplementation and dietary fat source on performance, blood serum metabolites, liver lipids, abdominal fat deposition, and tissue fatty acid composition in broiler chickens. Poult. Sci., 89 (8): 1651-1662.

Willis, W.L.; Iskhuemhen, O.S. and Ibrahim, S.A. (2007). Performance assessment of broiler chicks given mushroom extract alone or in combination with probiotics. Poult. Sci., 86: 1856-1860.

Younis, T.A.; A.A. Amer; Gehan, M. El-Mogazy and A.M. Kewan (2016).Efficacy of antibiotic growth promoter (AGP) alternatives suuplementation in the diet on broiler performance, intestinal morphology and cecalmicrobiota. Egypt. Poult. Sci. (II): 425-447.

Zangiabadi, H.R. and M. Torki (2010). The effects of a b-mannanase-based enzyme on growth performance and humoral immune response of broiler chickens fed diets containing graded levels of whole dates. Trop. Anim. Health Prod., 42: 1209-1217. 
تأثير خليط البروبيوتيك مع الإنزيمـات ومصدر دهون العليقة على الأداء الإنتاجي لبدارى التسمين خلال مرحلة الناهي

$$
\begin{aligned}
& \text { أحمد إبراهيم سليمان الفحام ـ هانى على ثابت- عبدالرحمن يوسف محمد عبدالهادى } \\
& \text { قسم إنتاج الدواجن، كلية الزراعة، جامعة عين شعس، القاهرة، مصر. }
\end{aligned}
$$

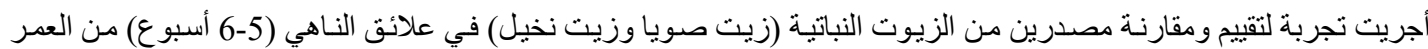

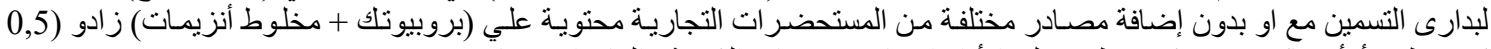

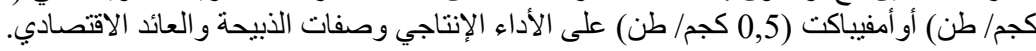

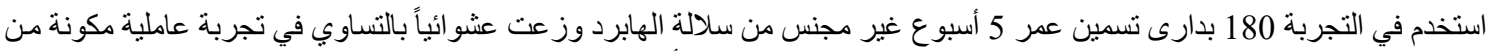

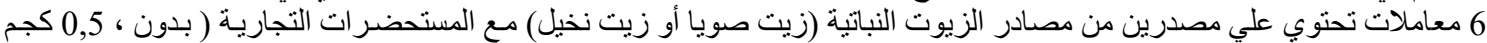
/طن زادو ، 0,5 كجم/طن أمفيباكت) بكل معاملة 3 مكررات وبكل مكرر 10 طيور.

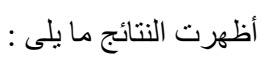

ــ لم يتأثر معنوياً الأداء الإنتاجي لبدارى التسمين (وزن الجسم الحي والزيادة الوزنية اليومية واستهلالك العلف اليومي ومعامل التحويل الغذائي) بمصدر الزيت أو المستحضرات التجائ التهارية أو التداخل بينهما.

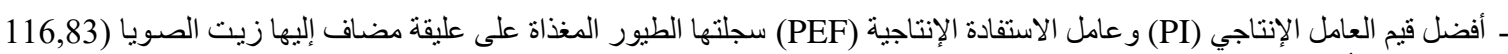
و 333,82) أو الز ادو (118,03 و 1337,24) على التو الي.

ـ أفضل قيم لمعامل تحويل البروتين (PCR) ومعامل تحويل الطاقة (ECR) سجلتها الطيور المغذاة على علائق مضاف إليها زيت النخيل أو الز ادو بدون فروق معنوية بين المعاملات.

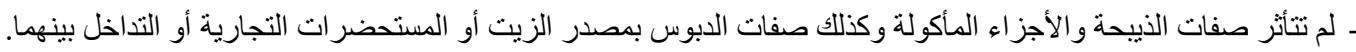
ـ سجلت الكفاءة الاقتصادية النسبية أعلى منوسط لبدارى التسمين المغذاة على علائق مضاف إليها زيت النخيل أو زيت الصويا مضاف إليه زادو (0,5 كجم/طن). توصي الدراسة باستخدام زيت النخيل أو زيت الصويا + الز ادو في علائق الناهي لبدارى التسمين للحصول على أفضل عائد اقتصادي بدون ألتأثير على الصفات الإنتاجية. 